\title{
Improvement of Soil Chemical Properties and Growth of Maize due to Biochar Application on Ultisol
}

\author{
Rianida Taisa ${ }^{1 *}$, Desi Maulida ${ }^{1}$, Abdul Kadir Salam², Muhammad Kamal ${ }^{3}$ and Ainin Niswati ${ }^{2}$ \\ ${ }^{1}$ Department of Food Crop Cultivation, Lampung State Polytechnic, Jl. Soekarno Hatta 10 Rajabasa, Bandar \\ Lampung, Indonesia. ${ }^{2}$ Department of Soil Science, ${ }^{3}$ Department of Agronomy, Faculty of Agriculture, \\ University of Lampung. Jl. Soemantri Brojonegoro No. 1, Bandar Lampung, Indonesia \\ *e-mail: rianidataisa@polinela.ac.id
}

Received July 26, 2019; Revised September 10, 2019; Accepted 13 September 2019

\begin{abstract}
Ultisols have poor soil characteristics, yet biochar is one of the technologies that can be applied as a soil enhancer to improve the soil quality. Biochar has succeeded in improving soil quality, through improving soil physical, chemical, and biological properties. This research aimed to improve the quality of soil chemical properties and growth of maize plant, as well as to find a combination between biochar type and dosage of biochar that is able to improve the chemical properties of Ultisols and/or the growth of maize plant. This research was conducted at the Greenhouse and Soil Science Laboratory, Faculty of Agriculture, University of Lampung. This study used a randomized block design (RBD) arranged in factorial with 3 factors and 3 replications. The first factor was the soil layer (topsoil and subsoil), the second factor was the type of biochar (biochar of cocoa shell and biochar of oil palm shell), and the third factor was the biochar dosage $(0,10 \%, 20 \%$, and $30 \%$ of $10 \mathrm{~kg}$ of oven dry weight soil). The results showed that (1) the application of biochar from the cocoa shell and oil palm shell on Ultisols improved some parts of soil chemical properties, namely CEC, organic $\mathrm{C}$, and $\mathrm{K}_{\text {exc }},(2)$ application of biochar from the cocoa shell and oil palm shell on Ultisols increased the plant height, the number of leaves, and the dry weight of maize, (3) application of biochar from the cocoa shell at a dosage of $20 \%$ was significantly improved CEC of Ultisols (4) application of biochar from the cocoa shell in top soil at a dosage of $30 \%$ significantly improved the soil organic $\mathrm{C}$ of Ultisol, (5) application of biochar from cacao shell at a dosage of $30 \%$ was significantly improved $\mathrm{K}_{\text {exc }}$ (6) application of biochar from oil palm shell at a dosage of $10 \%$ significantly increased maize plant growth.
\end{abstract}

Keywords: Biochar, Cation Exchange Capacity (CEC), exchangeable-K, maize, organic-C, Ultisol

\begin{abstract}
ABSTRAK
Ultisols memiliki karakteristik tanah yang buruk. Pemanfaatan biochar sebagai bahan pembenah tanah merupakan salah satu teknologi yang dapat diterapkan. Biochar telah diketahui dapat memperbaiki produktivitas tanah marginal baik secara fisika, kimia, dan biologi. Penelitian ini bertujuan untuk mempelajari pengaruh biochar terhadap perbaikan sifat kimia tanah dan respon tanaman jagung, serta mencari kombinasi jenis biochar dan takaran yang berpengaruh secara positif untuk memperbaiki sifat kimia tanah Ultisols dan atau pertumbuhan tanaman jagung. Penelitian ini dilaksanakan di Rumah Kaca dan Laboratorium Ilmu Tanah Fakultas Pertanian Universitas Lampung. Penelitian ini menggunakan Rancangan Acak Kelompok (RAK) yang disusun secara faktorial dengan 3 faktor dan 3 ulangan. Faktor pertama adalah kedalaman lapisan tanah (lapisan topsoil dan subsoil), faktor kedua adalah jenis biochar (biochar yang berasal dari kulit buah kakao dan biochar yang berasal dari tempurung kelapa sawit), dan faktor ketiga adalah takaran aplikasi biochar $(0,10 \%, 20 \%$, dan $30 \%$ dari $10 \mathrm{~kg}$ tanah setara berat kering oven). Hasil penelitian menunjukkan bahwa (1) aplikasi biochar asal kulit buah kakao dan tempurung kelapa sawit pada tanah Ultisols memperbaiki beberapa sifat kimia tanah seperti KTK tanah, C-organik, dan K-dd tanah, (2) Aplikasi biochar asal kulit buah kakao dan tempurung kelapa sawit pada tanah Ultisols meningkatkan tinggi tanaman, jumlah daun, dan bobot kering berangkasan tanaman jagung, (3) aplikasi biochar yang berasal dari kulit buah kakao dengan takaran $20 \%$ nyata mempebaiki KTK tanah Ultisols, (4) aplikasi biochar yang berasal dari kulit buah kakao pada lapisan atas dengan takaran $30 \%$ nyata mempebaiki C-organik tanah Ultisols, (5) aplikasi biochar yang berasal dari
\end{abstract}

J Trop Soils, Vol. 24, No. 3, 2019: 101-107

ISSN 0852-257X; E-ISSN 2086-6682 
kulit buah kakao dengan takaran 30\% nyata mempebaiki K-dd tanah Ultisols, (6) aplikasi biochar yang berasal dari tempurung kelapa sawit dengan takaran $10 \%$ nyata meningkatkan pertumbuhan tanaman jagung.

Kata kunci: Biochar, C-organik, Kapasitas Tukar Kation (KTK), K-dd, tanaman jagung, Ultisol

\section{INTRODUCTION}

Soil is one of the factors that play an important role in agriculture site, because soil is a growing medium and provides nutrients for plants. Agricultural land in Indonesia is dominated by Ultisols. Sumatra has the second highest area of Ultisols after Kalimantan (Prasetyo and Suriadikarta 2006). In terms of soil chemical properties, Ultisols are characterized by soil acidity $(\mathrm{pH})$ accompanied by high $\mathrm{Al}, \mathrm{Fe}$, and $\mathrm{Mn}$ content; high $\mathrm{P}$ adsorption, low cation exchange capacity (CEC), low organic $\mathrm{C}$ content and the availability of elements such as $\mathrm{N}, \mathrm{P}, \mathrm{K}, \mathrm{Ca}, \mathrm{Mg}$, and Mo are relatively low (Kaya 2009; Yuwono 2009). Therefore, input technology is needed to improve the quality of Ultisols by using soil amendments, such as biochar, which is a soil enhancer that has been known for a long time. The origin material of biochar is derived from agricultural and forestry waste that has undergone incomplete combustion (pyrolysis) in order to obtain charcoal containing activated carbon to be applied to the soil (Nurida et al. 2009; Lehmann and Joseph 2009).

The addition of biochar into the soil has been known to improve marginal soils like Ultisols physically, chemically and biologically. Based on the previous research, the addition of biochar to the soil could increase CEC, $\mathrm{pH}$, and availability of some nutrients (Glaser et al. 2002; Lehmann et al. 2003; Yamato et al. 2006; Soemeinaboedhy and Tejowulan 2007; Deenik et al. 2009; Baronti et al. 2010; Graber et al. 2010). In improving soil biology, the presence of biochar in the soil can be used as habitat for fungi and other soil microbes (Santi and Goenadi 2010; Noguera et al. 2010; Smith et al. 2010; Elad et al. 2011). Biochar has the ability to increase water holding capacity at an average of above $45 \%$, so it will be able to prevent the loss of fertilizer due to surface run off and leaching (Nurida et al. 2009; Ferizal 2011).

Hunt et al. (2010) studied that the maximum application dose for biochar depend on the soil type cultivated plants. Based on research conducted on several plants, biochar applied at a rate between $5 \%$ and $20 \%$ of the total soil volume showed a positive impact on crop production. In addition, several studies had also shown that the application of low concentrations of biochar were evident in increasing the growth of some plants (Rondon et al. 2007; Zhang et al. 2011).

This research aimed to study the effect of biochar on the chemical properties of Ultisols, the growth of maize plants, and to find the combination of types and dosage of biochar that would have a positive effect on improving the chemical properties of the soil and / or the growth of maize plants.

\section{MATERIALS AND METHODS}

\section{Research Location}

Biochar production was carried out in the Research Station of Indonesian Soil Research Institute in Taman Bogo, East Lampung. Analysis of soil chemical properties and maize plant tissue were carried out at the Soil Science Laboratory of the Faculty of Agriculture, University of Lampung. The pot experiment was conducted at the Greenhouse of the Faculty of Agriculture, University of Lampung.

\section{Biochar Production}

The agricultural wastes used as raw materials for biochar were cocoa shell and oil palm shell. The combustion process was carried out in the Research Station of Indonesian Soil Research Institute in Taman Bogo, East Lampung. Combustion was done by using a pyrolisator through incomplete combustion (pyrolysis) with a temperature of about $250-350{ }^{\circ} \mathrm{C}$ for approximately 1 hour (Nurida et al. 2009). After the combustion process was completed, the resulting biochar was sieved using $2 \mathrm{~mm}$ size sieve. The methods of biochar analysis were using standardized by the Indonesian Soil Research Institute (Sulaeman et al. 2005). The variables observed were $\mathrm{pH}, \mathrm{CEC}$, total N, organic-C, available-P, exchangeable-K, and $\mathrm{C} / \mathrm{N}$ ratio.

\section{Preparation of Planting Media}

The soil samples were using Ultisols that was taken from the Research Station of Indonesian Soil Research Institute in Taman Bogo, East Lampung. Soil samples were taken from two layers, namely the topsoil $(0-20 \mathrm{~cm})$ and the subsoil $(20-40 \mathrm{~cm})$. The size of polybag was $10 \mathrm{~kg}$. The soil samples were dried, smoothed using a grinder, and $2 \mathrm{~mm}$ 
sieved. A total of $10 \mathrm{~kg}$ soil, equivalent to the oven dry weight, was mixed with biochar according to the dose of each treatment. Biochar was applied before planting. The mixture of soil and biochar was applied by NPK fertilizer as a base fertilizer according to the recommendations, namely urea $1,5 \mathrm{~g}$ polybag $^{-1}$, SP-36 0,5 g polybag ${ }^{-1}$, and $\mathrm{KCl} 0,5 \mathrm{~g}$ polybag $^{-1}$. Before being put into a polybags the whole mixture was stirred evenly. After being put into the polybags, about $40 \%$ of the volume of soil was added to the water so it approaches the field capacity. The planting medium was then incubated for 2 weeks in a closed state before planting.

\section{Plant Analysis}

Each polybag was planted with two seeds of Lambada 1 sweet maize seeds, with a depth of 3 $\mathrm{cm}$ planting hole. One week after planting, in each polybag the best growth plants were selected. Plant maintenance was carried out by watering until the soil condition approaches the field capacity. Weed control was done manually, namely by weeding the weeds that grew in polybags. Harvesting was done when the plant reached the maximum vegetative phase ( 7 weeks after planting). Observation of plant growth parameters started one week after planting. The variables were plant height and number of leaves which were observed every week until 7 weeks after planting. And the supporting variables observed were dry weight of the trunk (7 weeks after planting).

\section{Soil Analysis}

The soil samples used for initial analysis had not been treated with biochar. Initial analysis of the soil chemical properties were carried out in the topsoil $(0-20 \mathrm{~cm})$ and the subsoil $(20-40 \mathrm{~cm})$. The variables observed were Cation Exchange Capacity (CEC) with $\mathrm{NH}_{4} \mathrm{OAc}$ method, organic-C with Walkey and Black method, and $\mathrm{K}_{\text {exc }}$ with $\mathrm{NH}_{4} \mathrm{OAc}$ method. While the soil samples used for the final analysis were taken from each polybag, by unpacking the polybags, then compiled from the area around the roots. Soil chemical properties observed in the final soil sample were CEC, organic $\mathrm{C}$, and $\mathrm{K}_{\mathrm{exc}}$. The method of soil analysis is using standardized by the Indonesian Soil Research Institute (Sulaeman et al. 2005).

\section{Experimental Design and Data Analysis}

The experimental design used in this study was a Randomized Block Design. The treatments were arranged in a factorial with three factors and three replications. The first factor was the depth of the soil layer (topsoil $0-20 \mathrm{~cm}$ and subsoil $20-40 \mathrm{~cm}$ ), the second factor was the type of biochar (biochar derived from the cocoa shell, and biochar derived from the oil palm shell), and the third factor was the application dosage of biochar ( $0 \%$ biochar, $10 \%$ biochar, 20\% biochar, and 30\% biochar from $10 \mathrm{~kg}$ of soil).

The data obtained were tested for homogeneity using the Bartlett Test and additivity by the Tukey Test. Those data who passed the test was continued with analysis of variance ( $F$ Test), then continued with the Honestly Significant Difference (HSD) Test at the $5 \%$ level.

\section{RESULTS AND DISCUSSION}

\section{Chemical Properties of Ultisol and Biochar}

The results of preliminary analysis of the chemical properties of Ultisols and biochar were presented in Table 1. Based on the criteria for assessment of soil analysis that had been standardized by the Indonesian Soil Research Institute (Sulaeman et al. 2005), Ultisols used in this study had acidic soil $(\mathrm{pH})$ reactions, CEC and total$\mathrm{N}$ were low, organic-C was very low as well as $\mathrm{P}-$ available and $\mathrm{K}_{\text {exc }}$. While the chemical properties of biochar derived from the cocoa shell had an alkaline soil reaction $(\mathrm{pH})$, low CEC, very high total-N, organic-C, available-P as well as exchangeable-K $\left(\mathrm{K}_{\mathrm{exc}}\right)$. The chemical properties of biochar derived from oil palm shell had somewhat alkaline soil reactions, low CEC, very low total-N and organic$\mathrm{C}$, very high available- $\mathrm{P}$, and moderate $\mathrm{K}_{\text {exc }}$.

Based on the results of the analysis, overall biochar derived from the cocoa shell had better chemical properties compared to biochar from palm oil shell. That statement had been revealed by Lehmann and Joseph (2009) and Hunt et al. (2010), which stated that the characteristics of the chemical properties and the quality of biochar were determined by the origin material of the biochar.

\section{Effect of Application of Biochar on CEC}

The results of the analysis of variance (Table 2) showed that the application of types and dosages of biochar had a significant effect in improving the CEC of Ultisols, while the soil layer had no significant effect. In addition there was a significant interaction between the types and the dosages of biochar on CEC.

Interactions between the types and dosages of biochar are presented in Table 3. It is shown that the treatment that had the highest CEC value was the soil which was applied by biochar from the cocoa shell at a dosage of $20 \%$. While the lowest CEC was on the soil that was applied by biochar from 
Table 1. Chemical properties of Ultisol and biochar.

\begin{tabular}{lcccc}
\hline Paremeter & Topsoil & Subsoil & $\begin{array}{c}\text { Cocoa Shell } \\
\text { Biochar }\end{array}$ & $\begin{array}{c}\text { Palm Oil Shell } \\
\text { Biochar }\end{array}$ \\
\hline $\mathrm{pH}$ & 4.89 & 5.37 & 9.90 & 7.87 \\
$\mathrm{CEC}(\mathrm{cmol}(+) \mathrm{kg}-1)$ & 5.12 & 7.91 & 11.60 & 10.60 \\
Total-N (\%) & 0.17 & 0.15 & 0.79 & 0.09 \\
Organic-C (\%) & 0.99 & 0.76 & 5.02 & 0.92 \\
Available-P (mg kg-1) & 4.33 & 1.15 & 22.02 & 80.54 \\
Exchangeable-K (cmol (+) kg-1) & 0.04 & 0.03 & 3.04 & 0.49 \\
C/N ratio & 5.81 & 5.09 & 6.33 & 9.93 \\
\hline
\end{tabular}

Table 2. Analysis of variance summary of CEC content on ultisols due to the application of several types of biochar.

\begin{tabular}{lccc}
\hline \multicolumn{1}{c}{ Diversity Source } & CEC $\left(\mathrm{cmol}(+) \mathrm{kg}^{-1}\right)$ & $\begin{array}{c}\text { Organic-C } \\
(\%)\end{array}$ & $\begin{array}{c}\text { Exchangeable-K } \\
\left(\mathrm{cmol}(+) \mathrm{kg}^{-1}\right)\end{array}$ \\
\hline Soil Layer & $\mathrm{ns}$ & $*$ & $*$ \\
Biochar Types & $*$ & $*$ & $*$ \\
Dosage & $*$ & $*$ & $*$ \\
Layer*Biochar Types & $\mathrm{ns}$ & $\mathrm{ns}$ & $\mathrm{ns}$ \\
Layer*Dosage & $\mathrm{ns}$ & $\mathrm{ns}$ & $\mathrm{ns}$ \\
Biochar types*Dosage & $*$ & $*$ & $\mathrm{~ns}$ \\
Layer*Biochar Types*Dosage & $\mathrm{ns}$ & $*$ & $*$ \\
\hline
\end{tabular}

Note: $\mathrm{ns}=$ not significantly different at $5 \%$ level of significance, ${ }^{*}=$ significantly at $5 \%$ level of significance

the cocoa shell at a dosage of $0 \%$. The soil that was applied by biochar from cocoa shell had a higher CEC value compared to biochar from oil palm shell, as a result the ability of biochar from oil palm shell to absorb cations was greater than the biochar from the cocoa shell. In addition Nigussie et al. (2012) also stated that the porous nature of biochar and the capacity of biochar that can be used as a medium by microorganisms for activity are thought to also play a role in improving soil quality and absorbing higher nutrients, so that the value of the CEC will also increase.

\section{Effect of Biochar Application on Soil Organic-C}

The results of the analysis of variance (Table 2) showed that the application of biochar types, dosages, and soil layers had a significant effect in improving the organic-C of Ultisol. In addition there

Table 3. Effect of interaction between biochar types and dosages on CEC of Ultisol (data were transformed into $\sqrt{\mathrm{x}}$ ).

\begin{tabular}{ccccc}
\hline \multirow{3}{*}{ Treatment } & \multicolumn{4}{c}{ Cation Exchange Capacity $\left(\mathrm{cmol}(+) \mathrm{kg}^{-1}\right)$} \\
\cline { 2 - 5 } & Without biochar & $10 \%$ biochar & $20 \%$ biochar & $30 \%$ biochar \\
& (B0) & (B1) & (B2) & (B3) \\
\hline Biochar from cocoa shell & $0.79 \mathrm{c}$ & $0.98 \mathrm{ab}$ & $1.00 \mathrm{a}$ & $0.99 \mathrm{ab}$ \\
& (A) & (A) & (A) & (A) \\
Biochar from oil palm shell & $0.84 \mathrm{a}$ & $0.85 \mathrm{a}$ & $0.82 \mathrm{a}$ & $0.87 \mathrm{a}$ \\
& (A) & (A) & (A) & (A) \\
& & HSD 5\% $=0.18$ & & \\
\hline
\end{tabular}

Note: The numbers followed by the same letters in the same column or row are not significantly different from the HSD test at $5 \%$ level. Lowercase letters are read horizontally, capital letters are read vertically. 
Table 4. Effect of interaction between biochar types and dosages on organic-C content in Ultisol.

\begin{tabular}{|c|c|c|c|c|c|}
\hline \multicolumn{2}{|c|}{ Treatments } & \multicolumn{4}{|c|}{ Organic $\mathrm{C}\left(\mathrm{g} \mathrm{kg}^{-1}\right)$} \\
\hline Biochar Types & Horizons & $\begin{array}{l}\text { Without biochar } \\
\text { (B0) }\end{array}$ & $\begin{array}{c}10 \% \text { biochar } \\
\text { (B1) }\end{array}$ & $\begin{array}{c}20 \% \text { biochar } \\
\text { (B2) }\end{array}$ & $\begin{array}{c}30 \% \text { biochar } \\
\text { (B3) }\end{array}$ \\
\hline $\begin{array}{l}\text { Biochar from } \\
\text { cocoa shell }\end{array}$ & $\begin{array}{c}\text { Topsoil Layer } \\
(0-20 \mathrm{~cm})\end{array}$ & $\begin{array}{c}0.61 \mathrm{c} \\
(\mathrm{A})\end{array}$ & $\begin{array}{c}0.98 \mathrm{~b} \\
\text { (A) }\end{array}$ & $\begin{array}{c}1.14 \mathrm{~b} \\
(\mathrm{~A})\end{array}$ & $\begin{array}{c}1.48 \mathrm{a} \\
(\mathrm{A})\end{array}$ \\
\hline & $\begin{array}{l}\text { Subsoil Layer } \\
(20-40 \mathrm{~cm})\end{array}$ & $\begin{array}{l}0.71 \mathrm{~b} \\
\text { (A) }\end{array}$ & $\begin{array}{l}0.60 \mathrm{~b} \\
\text { (A) }\end{array}$ & $\begin{array}{l}0.74 \mathrm{~b} \\
\text { (A) }\end{array}$ & $\begin{array}{c}1.09 \mathrm{a} \\
\text { (B) }\end{array}$ \\
\hline $\begin{array}{l}\text { Biochar from } \\
\text { oil palm shell }\end{array}$ & $\begin{array}{l}\text { Topsoil Layer } \\
(0-20 \mathrm{~cm})\end{array}$ & $\begin{array}{l}0.87 \mathrm{a} \\
\text { (A) }\end{array}$ & $\begin{array}{l}0.54 \mathrm{~b} \\
(\mathrm{~A})\end{array}$ & $\begin{array}{l}0.64 \mathrm{a} \\
(\mathrm{A})\end{array}$ & $\begin{array}{l}0.78 \mathrm{a} \\
(\mathrm{A})\end{array}$ \\
\hline & $\begin{array}{l}\text { Subsoil Layer } \\
(20-40 \mathrm{~cm})\end{array}$ & $\begin{array}{l}0.43 \mathrm{a} \\
\text { (B) }\end{array}$ & $\begin{array}{l}0.57 \mathrm{a} \\
\text { (A) }\end{array}$ & $\begin{array}{l}0.59 \mathrm{a} \\
\text { (A) }\end{array}$ & $\begin{array}{c}0.53 \mathrm{a} \\
\text { (A) }\end{array}$ \\
\hline
\end{tabular}

Note: The numbers followed by the same letters in the same column or row are not significantly different from the HSD test at $5 \%$ level. Lowercase letters are read horizontally, capital letters in are read vertically.

were significant interactions between the types of biochar, dosages, and soil layers on soil organic-C.

Interactions between biochar types, dosages, and layers are presented in Table 4. In general, the higher the dosage of biochar application, the higher the soil organic-C content. This is allegedly because the organic-C content in biochar was already high, therefore the presence of biochar indirectly contributes a number of carbon into the soil. The result showed that the highest soil organic-C content $(1.48 \%)$ was on the topsoil applied with biochar from cocoa shell at a dosage of $30 \%$. This might be due to the carbon content in the biochar from the cocoa shells were already very high $(5.02 \%)$. Whereas the lowest organic-C $(0.43 \%)$ was in the subsoil which was applied by biochar from the oil palm shell with a dosage of $0 \%$.

Table 5. Effect of interaction between biochar types and Kexc on ultisols.

\begin{tabular}{|c|c|c|c|c|}
\hline \multirow[b]{2}{*}{ Treatments } & \multicolumn{4}{|c|}{$\operatorname{Kexc}\left(\operatorname{cmol}(+) \mathrm{kg}^{-1}\right)$} \\
\hline & $\begin{array}{l}\text { Without biochar } \\
\text { (B0) }\end{array}$ & $\begin{array}{c}10 \% \text { biochar } \\
\text { (B1) }\end{array}$ & $\begin{array}{c}20 \% \text { biochar } \\
\text { (B2) }\end{array}$ & $\begin{array}{c}30 \% \text { biochar } \\
\text { (B3) }\end{array}$ \\
\hline Biochar from & $0.29 \mathrm{c}$ & $1.29 \mathrm{~b}$ & $1.50 \mathrm{a}$ & $1.61 \mathrm{a}$ \\
\hline cocoa shell & $(\mathrm{A})$ & $(\mathrm{A})$ & $(\mathrm{A})$ & $(\mathrm{A})$ \\
\hline Biochar from & $0.28 \mathrm{c}$ & $0.35 \mathrm{c}$ & $0.47 \mathrm{ab}$ & $0.52 \mathrm{a}$ \\
\hline oil palm shell & (A) & (B) & (B) & (B) \\
\hline \multicolumn{5}{|c|}{ HSD $5 \%=0.31$} \\
\hline
\end{tabular}

Table 6. F-test summary of maize plant growth.

\begin{tabular}{lccc}
\hline \multicolumn{1}{c}{ Diversity Source } & Plant height $(\mathrm{cm})$ & Number of leaves & Dry weight $(\mathrm{g})$ \\
\hline Layer & $\mathrm{ns}$ & $\mathrm{ns}$ & $\mathrm{ns}$ \\
Biochar Types & $*$ & $*$ & $*$ \\
Dosage & $*$ & $\mathrm{~ns}$ & $*$ \\
Layer*Biochar Types & $\mathrm{ns}$ & $\mathrm{ns}$ & $\mathrm{ns}$ \\
Layer*Dosage & $\mathrm{ns}$ & $\mathrm{ns}$ & $\mathrm{ns}$ \\
Biochar Types*Dosage & $\mathrm{ns}$ & $\mathrm{ns}$ & $*$ \\
Layer*Biochar Types*Dosage & $\mathrm{ns}$ & $\mathrm{ns}$ & $\mathrm{ns}$ \\
\hline
\end{tabular}

Note: $n s=$ not significantly different at $5 \%$ level of significance, $*=$ significantly at $5 \%$ level of significance 
Table 7. Effect of biochar types on plant height, number of leaves, and dry weight of maize plant.

\begin{tabular}{cccc}
\hline Biochar measurement & Plant height $(\mathrm{cm})$ & Number of leaves & Dry weight $(\mathrm{g})$ \\
\hline Biochar from cocoa shell & $72.82 \mathrm{~b}$ & $5.46 \mathrm{~b}$ & $2.84 \mathrm{~b}$ \\
Biochar from oil palm shell & $124.27 \mathrm{a}$ & $7.21 \mathrm{a}$ & $8.03 \mathrm{a}$ \\
\hline HSD 5\% & 15.96 & 0.89 & 2.69 \\
\hline
\end{tabular}

Note: The number followed by the same letter in the same column is not significantly different from the HSD test at the $5 \%$ level.

Table 8. Effect of biochar dosages on plant height and dry weight of maize plant.

\begin{tabular}{ccc}
\hline Biochar dosage & Plant height $(\mathrm{cm})$ & Dry weight $(\mathrm{g})$ \\
\hline $0 \%$ & $95.91 \mathrm{ab}$ & $3.46 \mathrm{~b}$ \\
$10 \%$ & $123.52 \mathrm{a}$ & $9.25 \mathrm{a}$ \\
$20 \%$ & $97.38 \mathrm{ab}$ & $5.17 \mathrm{ab}$ \\
$30 \%$ & $77.37 \mathrm{~b}$ & $3.84 \mathrm{~b}$ \\
\hline HSD 5\% & 30.11 & 5.09 \\
\hline
\end{tabular}

Note: The numbers followed by the same letters in the same column are not significantly different from the HSD test at 5\% level.

\section{Effect of Biochar Application on Exchangeable- $\mathbf{K}$}

The results of the analysis of variance (Table 2) showed that the application of biochar types, dosages, and soil layers had a significant effect in improving the $\mathrm{K}_{\text {exc }}$ on ultisols. In addition there were significant interactions between the types of biochar and the content of $\mathrm{K}_{\mathrm{exc}}$ in soil.

Interactions between biochar types and quantities are presented in Table 5. The higher the biochar dosage applied to the soil, the higher the measured $\mathrm{K}_{\text {exc }}$. This was presumably due to the high $\mathrm{K}$ content of biochar, the alkaline condition of biochar, and the CEC content of biochar which was already high. The highest $\mathrm{K}_{\mathrm{exc}}$ was in the soil that was applied by biochar from cocoa shell at a dosage of $30 \%$. While the lowest $\mathrm{K}_{\text {exc }}$ was in the subsoil which was applied by biochar from the cocoa shell at a dosage of $0 \%$.

\section{Effect of Application of Several Biochar Types on the Growth of Maize}

The results of the analysis of plant height, number of leaves, and dry weight are presented in Table 6. Based on the research data, the application of biochar types increased the height, the number of leaves, and the stall dry weight of maize plants. While the actual dosage increased the plant height and the dry weight of the maize plant.
The effect of biochar types on the plant height and the dry weight of maize plants are presented in Tables 7 and 8. Based on Table 7 shows that biochar from oil palm shells was better in increasing plant growth compared to biochar derived from cocoa shell. Table 8 shows that the plant height, the $10 \%$ biochar dosage was significantly different from the $30 \%$ dosage, but it was not different from the biochar dosages of $0 \%$ and $20 \%$. Whereas the dry weight of maize plants using $10 \%$ biochar application was different from $0 \%$ and $30 \%$, but it was not different from $20 \%$. This shows that the provision of biochar with a low dosage had an effect on the plant height and the dry weight of maize plants.

\section{CONCLUSIONS}

Application of biochar from cocoa shell and oil palm shells on Ultisol improves some chemical properties of soil such as $\mathrm{CEC}$, organic-C, and $\mathrm{K}_{\text {exc }}$. Application of biochar from cocoa shells and oil palm shells on Ultisol increased the plant height, the number of leaves, and the dry weight of maize plants. Application of biochar from the cocoa shell at a dosage of $20 \%$ significantly increased the CEC on Ultisol. Application of biochar derived from the cocoa shell in top soil at a rate of $30 \%$ significantly improves the soil organic-C on Ultisol. Application of biochar from the cocoa shell at a dosage of $30 \%$ significantly increased the $\mathrm{K}_{\text {exc }}$ on Ultisol. Application 
of biochar from oil palm shell at a dosage of 10\% significantly increased the growth of maize plant.

\section{ACKNOWLEDGEMENTS}

Thank you for Ristekdikti was financially supported this research and Soil research institute in Taman Bogo East Lampung for providing biochar and soil sample.

\section{REFERENCES}

Baronti S, G Alberti, GD Vedove, FD Gennaro, G Fellet, L Genesio, F Miglietta, A Peressotti, and FP Vaccari. 2010. The biochar option to improve plant yields: first result from some field and pot experiments in Italy. Ital J Agron 5: 3-11.

Deenik JL, AT McClellan and G Uehara. 2009. Biochar volatile matter content effects on plant growth and nitrogen transformations in a tropical soil. Western Nutrient Management Conference. Vol 8. Salt Lake City, UT.

Elad Y, E Cytryn, YM Harel, B Lew and ER Geabber. 2011. The biochar effect: plant resistence to biotic stresses. Phytopathol Mediterr 50: 335-349.

Ferizal M. 2011. Arang hayati (Biochar) sebagai bahan pembenah tanah. Balai Pengkajian Teknologi Pertanian Aceh. Edisi Khusus Penas XIII, 22 Juni 2011. (in Indonesian).

Glaser B, J Lehmann and W Zech. 2002. Ameliorating physical and chemical properties of highly weathered soils in the tropics with charcoal - a review. Biol Fertil Soils 35: 219-230.

Graber ER, YM Harel, M Kolton, E Cytryn, A Silber, DR David, L Tsechansky, M Borenshtein and Y Elad. 2010. Biochar impact on development and productivity of pepper and tomato grown in fertigated soilless media. Plant Soil 337: 481-496.

Hunt J, M Du Ponte, D Sato and A Kawabata. 2010. The basic of biochar: A natural soil amandement. Soil and Crop Management. College of Tropical Agriculture and Human Resources. University of Hawai'i Manoa.

Kaya E. 2009. Ketersediaan fosfat, serapan fosfat, dan hasil tanaman jagung (Zea mays L.) akibat pemberian bokashi ela sagu dengan pupuk fosfat pada Ultisols. J Ilmu Tanah Lingk 9: 30-36. (in Indonesian).

Lehmann J and S Joseph. 2009. Biochar Environmental management. Earthscan. London. 416p.

Lehmann J, JP Da Silva Jr, C Steiner, T Nehls, W Zech and B Glaser. 2003. Nutrient availability and leaching in an archaeological Anthrosol and a Ferralsol of the Central Amazon basin: fertilizer, manure and charcoal amendments. Plant Soil 249: 343-357.
Nigussie A, E Kissi, M Misganaw and G Ambaw. 2012. Effect of biochar application on soil properties and nutrient uptake of lettuces (Lactuca sativa) grown in chromium polluted soils. Am-Eur J Agric Environ Sci 12:369-376.

Noguera D, M Rondon, KM Laossi, V Hoyos, P Lavelle, MHCD Carvalho and S Barot. 2010. Contrasted effect of biochar and earthworms on rice growth and resource allocation in different soils. Soil Biol Biochem 42: 1017-1027.

Nurida NL, Ai Dariah and A Rachman. 2009. Kualitas limbah pertanian sebagai bahan baku pembenah tanah berupa biochar untuk rehabilitasi lahan. Balai Penelitian Tanah. Bogor. (in Indonesian).

Prasetyo BH and DA Suriadikarta. 2006. Karakteristik, potensi, dan teknologi pengelolaan tanah ultisol untuk pengembangan pertanian lahan kering di Indonesia. J Litbang Pertanian 25: 39-47.

Rondon MA, J Lehmann, J Ramirez and M Hurtado. 2007. Biological nitrogen fixation by common beans (Phaseolus vulgaris L.) increases with bi0-char additions. Biol Fertil Soils 43: 699-708.

Santi LP and DH Goenadi. 2010. Pemanfaatan biochar sebagai pembawa mikroba untuk pemantap agregat tanah Ultisol dari Taman Bogo-Lampung. Menara Perkebunan 78: 52-60. (in Indonesian).

Smith JL, HP Collins and VL Bailey. 2010. The effect of young biochar on soil respiration. Soil Biol Biochem 42: 2345-2347.

Soemeinaboedhy IN and RS Tejowulan. 2007. Pemanfaatan berbagai macam arang sebagai sumber unsur hara P dan K serta sebagai pembenah tanah. Agroteksos 17: 114-122. (in Indonesian).

Sulaeman, Suparto and Eviati. 2005. Petunjuk Teknis Analisis Kimia Tanah, Tanaman, Air, dan Pupuk. Balai Penelitian Tanah. Bogor. $136 \mathrm{hlm}$. (in Indonesian).

Yamato M, Y Okimori, IF Wibowo, S Anshori and M Ogawa. 2006. Effects of the application of charred bark of acacia mangium on the yield maize, cowpea and peanut, and soil chemical properties in South Sumatra, Indonesia. Soil Sci Plant Nutr 52: 489-495.

Yuwono NW. 2009. Membangun kesuburan tanah di lahan marginal. J Ilmu Tanah Lingk 9: 137-141. (in Indonesian).

Zhang A, Y Liu, G Pan, Q Hussain, L Li, J Zheng and X Zhang. 2012. Effect of biochar amendement on maize yield and greenhouse gas emissions from a soil organic carbon poor calcareous loamy soil from central china plain. Plant Soil 351: 263-275. 